Fifth International Conference on Sustainable Construction Materials and

Technologies. http://www.claisse.info/Proceedings.htm

SCMT5

Kingston University London, UK, July 14 - 17, 2019

\title{
BRICK FINE AGGREGATE AND LADLE FURNACE SLAG AS ALTERNATIVE TO NATURAL RIVER SAND
}

\author{
Tarek U. Mohammed ${ }^{1 a}$, Md. Mahafizul Hassan², Md Nafiur Rahman ${ }^{1 b}$, Shibly Mostafiz \\ Apurbo $^{3}$
}

${ }^{1}$ Department of Civil and Environmental Engineering, Islamic University of Technology (IUT), Gazipur 1704, Bangladesh, ${ }^{1 a}$ Email: <tarek@iut-dhaka.edu>, ${ }^{1 b}$ Email: 〈nafi@iut-dhaka.edu>, ${ }^{2}$ Department of Civil Engineering, University of Asia Pacific (UAP), Dhanmondi, Dhaka, ${ }^{2}$ Email: <engr.mhassan@yahoo.com>

${ }^{3}$ Department of Civil Engineering, Presidency University, Banani, Dhaka, ${ }^{3}$ Email: <apurbo@iutdhaka.edu>

\begin{abstract}
An experimental investigation was carried out to explore the possibility of utilizing brick fine aggregate (BFA) and ladle furnace slag (LFS) as alternative to natural river sand as fine aggregates in concrete. For this, cylindrical concrete specimens of $100 \mathrm{~mm}$ x $200 \mathrm{~mm}$ size were made by varying the replacement ratios of natural river sand to the alternative fine aggregates, $\mathrm{W} / \mathrm{C}$ ratios, and fine aggregate-to-total aggregate (f/a) volume ratios. Workability of concrete was measured by slump cone test. The concrete specimens were cured under water and tested at 28 days for compressive strength, tensile strength, and modulus of elasticity of concrete.

From the experimental results, it was observed that BFA absorbs more water compared to natural river sand and LFS. With the increasing replacement ratios of the alternative fine aggregates, the workability of concrete increased for the concrete made with LFS but decreased for the concrete made with BFA. Compressive strength of concrete increased with the increased replacement of natural river sand by BFA and LFS up to $30 \%$ and $20 \%$ replacement ratios respectively. The trend of tensile strength and modulus of elasticity of concrete were found similar to that of the compressive strength of concrete. It was concluded that it is possible to utilize BFA and LFS as alternative fine aggregates to natural river sand in concrete without reducing the compressive strength of concrete for up to $30 \%$ and $20 \%$ replacement ratios respectively. Utilization of BFA and LFS as fine aggregates will reduce the demand of natural river sand in the construction works and may help toward achieving the sustainability of construction materials in Bangladesh.
\end{abstract}

Keywords: Brick, Ladle Furnace Slag, Fine Aggregate, Compressive Strength, Tensile Strength, Workability, Modulus of Elasticity. 


\section{INTRODUCTION}

Bangladesh is a plain and delta land which has very limited sources for coarse aggregate and fine aggregate to make concrete. Due to the lack of availability of stone aggregate, clay bricks are widely used to make coarse aggregate which has tremendous input to environmental pollution. Natural river sand is mainly used as fine aggregate in concrete, which is mostly extracted from the riverbed by dredging. Due to huge construction works related to several mega projects as well as small scaled government and private projects, it is expected that in the very near future, there will be a significant amount of depletion of natural fine aggregate.

Therefore, it becomes essential to explore possible alternative fine aggregates for the sustainable development of construction materials. As alternative to natural river, brick fine aggregate (locally known as surki) may be used as fine aggregate in concrete. There are more than 6000 brick industries in Bangladesh due to the high demand of bricks as construction material. Crushing of these bricks in the construction sites produces a significant amount of fine materials which are not utilized in most cases. Although many attempts were made in order to understand the suitability of crushed brick chips as coarse aggregate in concrete, very few studies were found with brick fine aggregate in concrete (Akhtaruzzaman and Hasnat, 1986, 1983; Bektas et al., 2009; Cachim, 2009; Debieb and Kenai, 2008; Mohammed et al., 2015; Mohammed and Hassan, 2015; Mohammed and Mahmood, 2016). Therefore, a thorough investigation is necessary to understand the suitability of brick fine aggregate as fine aggregate in concrete.

Currently, the annual production of steel in Bangladesh has raised to about 3 million Metric Tons. The steel industries in Bangladesh commonly use induction furnaces for rerolling of steel and ladle refined furnaces are used for refining of molten steel producing the amorphous ladle furnace slag or LFS as a by-product. An attempt was made to investigate the possibility of utilization of induction furnace slag as coarse aggregate in concrete (Mohammed et al., 2016). Many researchers had studied the suitability of incorporating fine slag as fine aggregate in concrete (Kockal, 2016; Pellegrino et al., 2013). However, few literatures were found where the suitability of ladle furnace slag as fine aggregate in concrete was discussed (Adolfsson et al., 2011; John and John, 2013). Therefore, further investigations are necessary in order to understand the suitability of LFS as fine aggregate in concrete.

With the above-mentioned background, a detailed experimental investigation was carried out by replacing natural river sand with BFA, and LFS by varying replacement ratio (0 50\% for BFS and $0 \sim 30 \%$ for LFS), W/C (0.5 and 0.55), sand-to-aggregate volume ratio (f/a) (0.44 and 0.48), etc. The results will be useful to understand the possibility of replacing natural river sand by these alternative by-product materials.

\section{EXPERIMENTAL METHOD}

Fine aggregates investigated in this study include brick fine aggregate (BFA) and ladle refined furnace slag (LFS) aggregate as shown in Fig. 1. Brick fine aggregate (BFA) samples were collected from three different sources of brick aggregate (denoted as S1, S2, and S3) where the crushing of brick produced BFA as a by-product of brick coarse aggregate. The slags used in this 
study were collected from a local steel manufacturing company where selected ferrous scraps are used to produce steel-based products. Scraps are melted in the induction furnace. Slag is removed from the furnace at regular intervals. This slag is often termed as induction furnace slag (IFS). The molten metal is transferred into a ladle refined furnace to facilitate refinement of the metal. Fine slag collected from the ladle refined furnace is often called as ladle furnace slag or LFS.

Natural river sand was used as the controlled fine aggregate for comparison with different alternatives. The fine aggregates were tested for specific gravity, absorption capacity, fineness modulus, and SSD unit weight as per ASTM specifications. The coarse aggregates were also tested for specific gravity, absorption capacity, fineness modulus, SSD unit weight, and abrasion as per ASTM specifications. The physical properties of coarse and fine aggregates are summarized in Table 1 and Table 2 respectively. The maximum size of coarse aggregate was $19 \mathrm{~mm}$. The grading of coarse aggregates was controlled as per the requirement of ASTM C33 as shown in Fig. 2a. The brick fine aggregate sample, BFA (S-1) was relatively coarser compared to the ASTM specifications. The fine aggregate sample, LFS was relatively finer compared to the ASTM specifications. CEM type II/B-M (as per BDS EN197-1:2000) was used which consists of 65-79\% clinker and $21-35 \%$ of mineral admixture and gypsum.
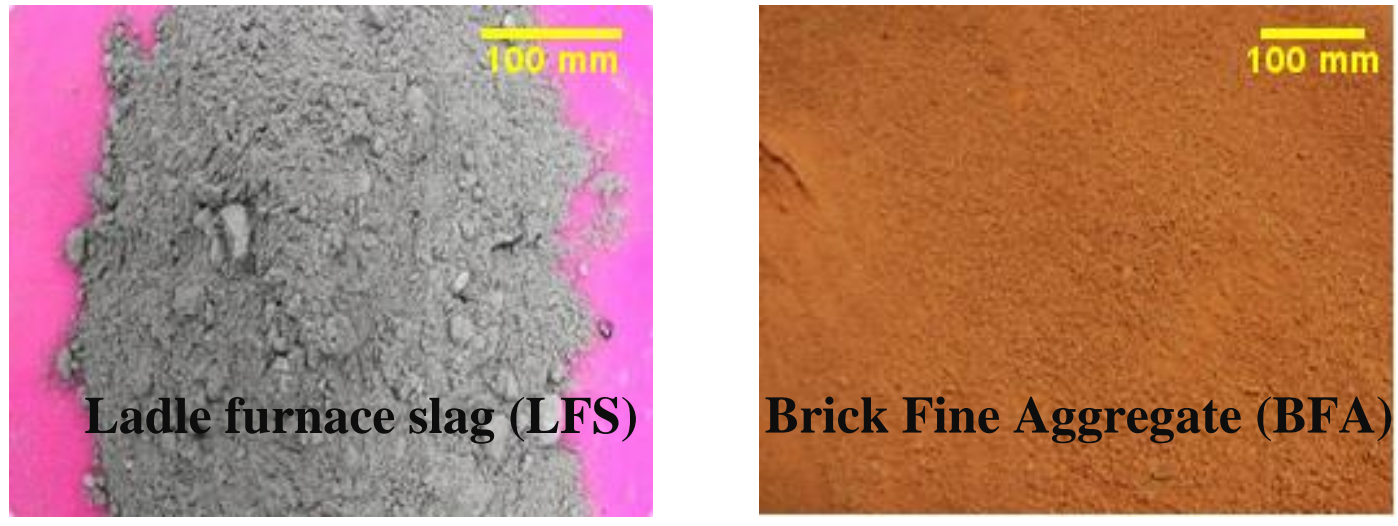

Fig. 1. Fine aggregates investigated in this study

Table 1. Physical properties of coarse aggregates investigated

\begin{tabular}{|c|c|c|c|c|c|}
\hline Type of coarse aggregate & $\begin{array}{c}\text { Fineness } \\
\text { modulus } \\
(\text { FM) }\end{array}$ & $\begin{array}{c}\% \\
\text { Wear }\end{array}$ & $\begin{array}{c}\text { Bulk } \\
\text { specific } \\
\text { gravity in } \\
\text { SSD } \\
\text { condition }\end{array}$ & $\begin{array}{c}\text { Absorption } \\
\text { capacity } \\
(\%)\end{array}$ & $\begin{array}{c}\text { Unit } \\
\text { weight } \\
\left(\mathrm{kg} / \mathrm{m}^{3}\right)\end{array}$ \\
\hline Brick Aggregate (BA), S1 & \multirow{4}{*}{$\begin{array}{l}\text { Controlled } \\
\text { as per } \\
\text { ASTM } \\
\text { C33 }\end{array}$} & 35.0 & 1.7 & 13.1 & 1125 \\
\hline Brick Aggregate (BA), S2 & & 33.0 & 1.9 & 15.7 & 1351 \\
\hline Brick Aggregate (BA), S3 & & 30.0 & 2.1 & 11.1 & 1170 \\
\hline $\begin{array}{l}\text { Brick Aggregate (used with } \\
\text { LFS fine slag) }\end{array}$ & & 34.1 & 2.15 & 19.0 & 1214 \\
\hline
\end{tabular}


Table 2. Physical properties of fine aggregates investigated

\begin{tabular}{|c|c|c|c|c|}
\hline Type of fine aggregate & $\begin{array}{c}\text { Fineness } \\
\text { modulus } \\
(\text { FM) }\end{array}$ & $\begin{array}{c}\text { Bulk specific } \\
\text { gravity in SSD } \\
\text { condition }\end{array}$ & $\begin{array}{c}\text { Absorption } \\
\text { capacity } \\
(\mathbf{\%})\end{array}$ & $\begin{array}{c}\text { Unit } \\
\mathbf{w e i g h t} \\
\left(\mathbf{k g} / \mathbf{m}^{\mathbf{3}}\right)\end{array}$ \\
\hline Natural River Sand (SS) & 2.55 & 2.55 & 5.1 & 1497 \\
\hline $\begin{array}{c}\text { Brick Fine Aggregate } \\
\text { (BFA), S1 }\end{array}$ & 3.90 & 2.10 & 13.5 & 1322 \\
\hline $\begin{array}{c}\text { Brick Fine Aggregate } \\
\text { (BFA), S2 }\end{array}$ & 3.20 & 2.20 & 15.0 & 1211 \\
\hline $\begin{array}{c}\text { Brick Fine Aggregate } \\
\text { (BFA), S3 }\end{array}$ & 2.70 & 2.10 & 11.0 & 1615 \\
\hline $\begin{array}{c}\text { Ladle Furnace Slag } \\
\text { (LFS) }\end{array}$ & 2.36 & 2.61 & 2.7 & 1400 \\
\hline
\end{tabular}

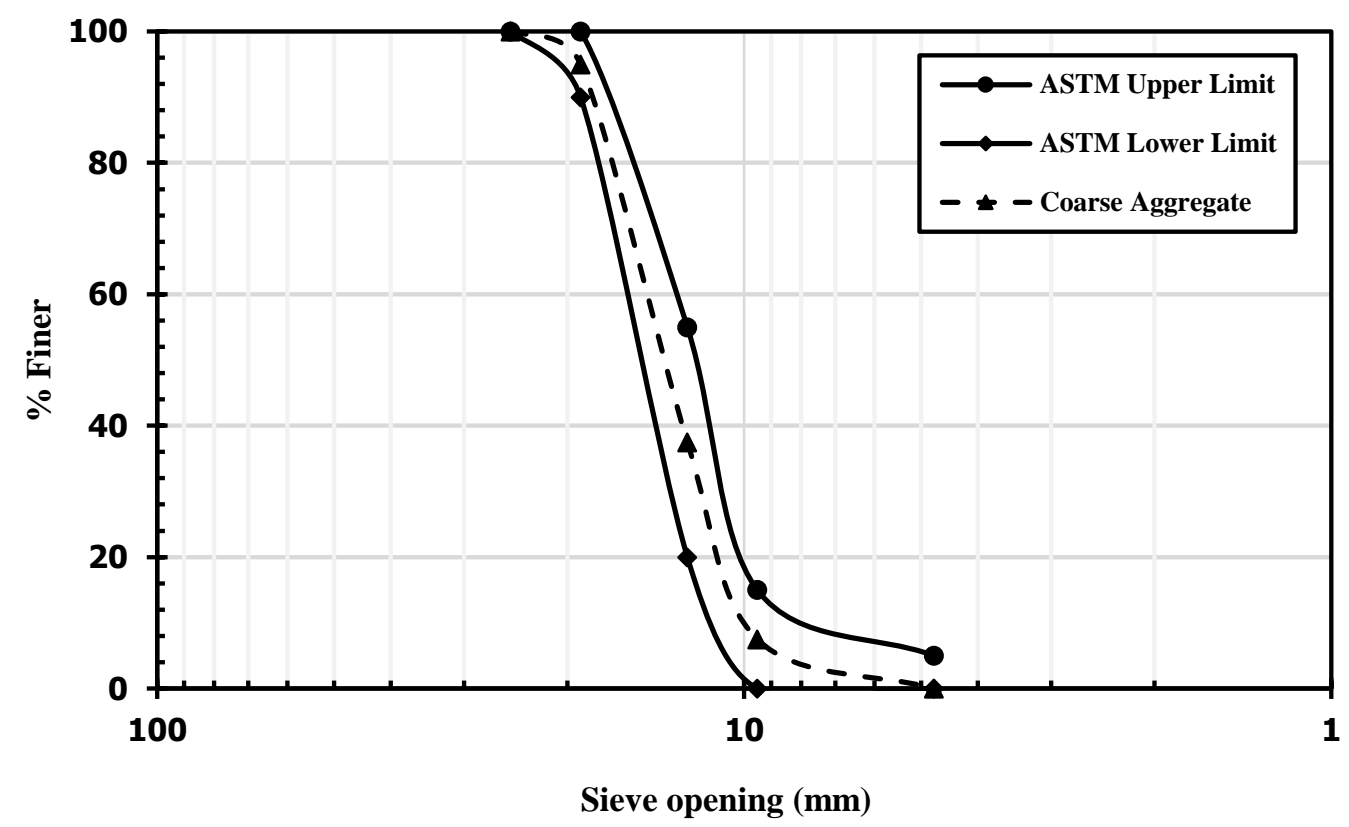

Fig. 2a. Gradation of coarse aggregate. 


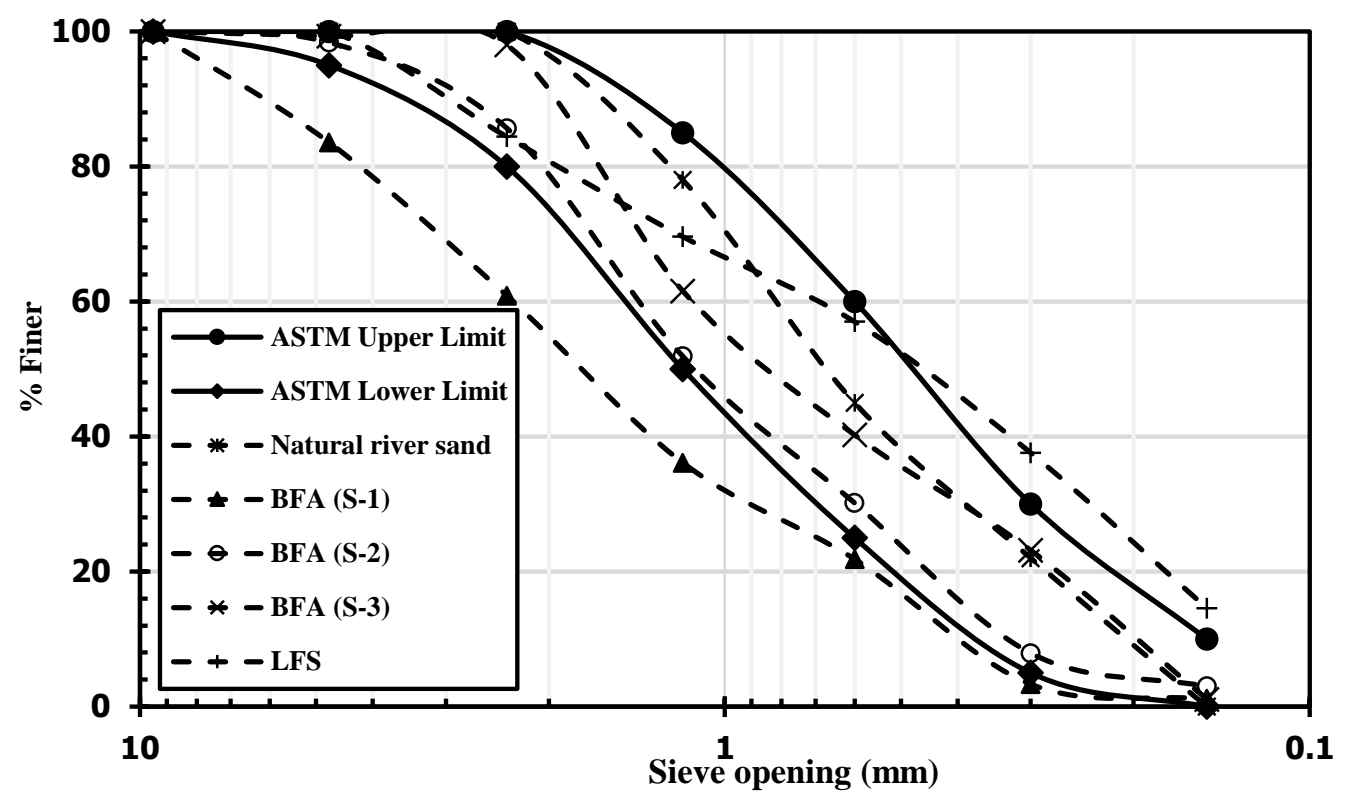

Fig. 2b. Gradation of fine aggregate.

To investigate the effect of BFA in concrete, $100 \mathrm{~mm} \times 200 \mathrm{~mm}$ cylindrical concrete specimens were made by incorporating $0 \%, 10 \%, 20 \%, 30 \%, 40 \%$, and $50 \%$ brick fine aggregate as a replacement of natural river sand where fine aggregate-to-total aggregate (f/a) volume ratio was 0.40 , water to cement (W/C) ratio were 0.50 and 0.55 , and cement content was fixed at $340 \mathrm{~kg} / \mathrm{m}^{3}$ for all the cases. Brick coarse aggregates from the respective sources (S1, S2, S3) of BFA were used as coarse aggregate in making concrete. Cases investigated for all concrete specimens made with BFA are summarized in Table 3. Concrete specimens were also made by replacing natural sand with ladle refined furnace slag at $0 \%, 10 \%, 20 \%$ and $30 \%$ replacement ratios with fine aggregate-to-total aggregate (f/a) volume ratios of 0.40 and 0.48 , water to cement (W/C) ratios of 0.45 , and cement contents of $340 \mathrm{~kg} / \mathrm{m}^{3}$. Brick coarse aggregate was used as coarse aggregates in concrete. All the cases investigated for concrete specimens made with LFS are summarized in Table 4.

The concrete specimens were casted in steel molds and kept under a humid environment for $24 \mathrm{~h}$. The specimens were demolded after $24 \mathrm{~h}$ of casting and kept underwater till the age of testing. The concrete specimens were tested for compressive strength, tensile strength, and modulus of elasticity at the age of 28 days as per ASTM specifications.

\section{RESULTS AND DISCUSSION}

\section{Physical Properties of Alternative Aggregates}

It can be observed from Table 1 that the specific gravity of ladle furnace slag (LFS) was the highest (2.61) among the fine aggregates investigated. Regardless of the sources, the specific gravity of brick fine aggregates (BFA) used in this study were found to be almost similar. In terms of 
absorption capacity, the fine aggregates can be ordered as BFA > natural river sand > LFS. It can be observed from the Fig. 2b that the gradation curve of BFA (S1) lies under the ASTM lower limit, which indicates that the aggregate is substantially coarser than the other fine aggregates investigated. In case of ladle furnace slag, it is observed from Fig. $2 b$ that the finer portion of their gradation curves lies above the ASTM upper limit indicating that they are substantially finer compared to other fine aggregates investigated in this study.

\section{Workability of Concrete}

The workability of concrete made with brick fine aggregate collected from different sources (S1, S2, S3) is shown in Fig. 3. It is observed from the figure that the workability of concrete reduced with the increase of replacement ratios of brick fine aggregate. This is because brick fine aggregates had more absorption capacity compared to natural river sand. Also, the brick fine aggregate is angular in shape where the natural rive sand is a round shaped fine aggregate.

The workability of concrete prepared with $0 \%, 10 \%, 20 \%$ and $30 \%$ replacements of river sand by LFS aggregate are presented in Fig. 4. The results show that the workability of concrete is reduced with the increase of percentage replacement of river sand by LFS. The workability of concrete is increased for a small amount of replacement however it reduces for the higher amount of replacements. The reason behind initial increase in workability may be attributed to the low absorption capacity of LFS aggregate (as shown in Table 2). Beyond 10\% replacement, the workability reduced as LFS aggregate contains more fine particles compared to river sand (Fig. 2b). Moreover, LFS particles are more angular in shape in comparison to river sand particles, which may be attributed to concrete exhibiting low workability beyond $10 \%$ replacement of river sand by LFS aggregate. For f/a $=0.48$, brick aggregate concrete resulted in almost zero slump beyond $30 \%$ replacement of river sand by LFS. Therefore, the scope of this study was kept limited to $30 \%$ replacement of river sand by LFS aggregate. Nevertheless, studies may still be planned to investigate replacements greater than $30 \%$ by improving workability of fresh concrete using high range water reducers.

Table 3. Mix proportions of concrete specimens made with brick fine aggregate

\begin{tabular}{|c|c|c|c|c|c|c|c|c|c|c|c|}
\hline \multirow{3}{*}{$\begin{array}{c}\text { Sources } \\
\text { of } \\
\text { Brick } \\
\text { Sample }\end{array}$} & \multirow{2}{*}{\multicolumn{2}{|c|}{ Replacement (\%) }} & \multirow[b]{3}{*}{ W/C } & \multirow[b]{3}{*}{$\mathbf{f} / \mathbf{a}$} & \multicolumn{5}{|c|}{ Mix proportions, $\mathrm{kg} / \mathrm{m}^{3}$} & \multirow{3}{*}{$\begin{array}{c}\text { Unit } \\
\text { Weight } \\
\text { of fresh } \\
\text { concrete } \\
\left(\mathbf{k g} / \mathbf{m}^{3}\right)\end{array}$} & \multirow{3}{*}{$\begin{array}{c}\text { 28-day } \\
\text { comp. } \\
\text { strength } \\
(\mathrm{MPa})\end{array}$} \\
\hline & & & & & \multirow[b]{2}{*}{ Cement } & \multirow[b]{2}{*}{ Water } & \multirow[b]{2}{*}{$\begin{array}{c}\text { Coarse } \\
\text { aggregate }\end{array}$} & \multicolumn{2}{|c|}{ Fine Aggregate } & & \\
\hline & $\begin{array}{c}\text { Natural } \\
\text { River } \\
\text { Sand }\end{array}$ & $\begin{array}{c}\text { Brick } \\
\text { Fine } \\
\text { Aggregate }\end{array}$ & & & & & & $\begin{array}{c}\text { Natural } \\
\text { River } \\
\text { Sand }\end{array}$ & $\begin{array}{c}\text { Brick } \\
\text { Fine } \\
\text { Aggregate }\end{array}$ & & \\
\hline \multirow{12}{*}{ S1 } & 100 & 0 & \multirow{6}{*}{0.5} & \multirow{12}{*}{0.4} & \multirow{12}{*}{340} & \multirow{6}{*}{170} & \multirow{6}{*}{706} & 0 & 1081 & 1957 & 24.29 \\
\hline & 90 & 10 & & & & & & 71 & 973 & 1920 & 28.88 \\
\hline & 80 & 20 & & & & & & 141 & 865 & 1882 & 28.40 \\
\hline & 70 & 30 & & & & & & 212 & 757 & 1845 & 30.42 \\
\hline & 60 & 40 & & & & & & 283 & 648 & 1807 & 21.92 \\
\hline & 50 & 50 & & & & & & 353 & 540 & 1769 & 20.35 \\
\hline & 100 & 0 & \multirow{6}{*}{0.55} & & & \multirow{6}{*}{187} & \multirow{6}{*}{689} & 0 & 1054 & 1930 & 23.29 \\
\hline & 90 & 10 & & & & & & 69 & 948 & 1893 & 23.65 \\
\hline & 80 & 20 & & & & & & 138 & 843 & 1857 & 24.71 \\
\hline & 70 & 30 & & & & & & 207 & 738 & 1821 & 25.16 \\
\hline & 60 & 40 & & & & & & 276 & 633 & 1785 & 20.34 \\
\hline & 50 & 50 & & & & & & 345 & 527 & 1748 & 18.14 \\
\hline
\end{tabular}




\begin{tabular}{|c|c|c|c|c|c|c|c|c|c|}
\hline \multirow{12}{*}{$\mathrm{S} 2$} & 100 & 0 & \multirow{6}{*}{0.5} & \multirow{6}{*}{170} & \multirow{6}{*}{831} & 0 & 887 & 1888 & 26.87 \\
\hline & 90 & 10 & & & & 71 & 798 & 1870 & 28.16 \\
\hline & 80 & 20 & & & & 141 & 709 & 1851 & 28.30 \\
\hline & 70 & 30 & & & & 212 & 621 & 1834 & 29.91 \\
\hline & 60 & 40 & & & & 283 & 532 & 1816 & 24.05 \\
\hline & 50 & 50 & & & & 353 & 443 & 1797 & 20.20 \\
\hline & 100 & 0 & & & & 0 & 865 & 1863 & 26.87 \\
\hline & 90 & 10 & & & & 71 & 778 & 1847 & 27.86 \\
\hline & 80 & 20 & 055 & 187 & 811 & 141 & 692 & 1831 & 28.62 \\
\hline & 70 & 30 & 0.55 & 181 & 811 & 212 & 606 & 1816 & 25.19 \\
\hline & 60 & 40 & & & & 283 & 519 & 1800 & 18.90 \\
\hline & 50 & 50 & & & & 353 & 432 & 1783 & 18.98 \\
\hline & 100 & 0 & & & & 0 & 748 & 1791 & 26.49 \\
\hline & 90 & 10 & & & & 71 & 673 & 1787 & 28.45 \\
\hline & 80 & 20 & 05 & 170 & 873 & 141 & 598 & 1782 & 28.55 \\
\hline & 70 & 30 & 0.5 & $1 / 0$ & $0 / 3$ & 212 & 524 & 1779 & 29.71 \\
\hline & 60 & 40 & & & & 283 & 449 & 1775 & 20.67 \\
\hline $\mathrm{S} 3$ & 50 & 50 & & & & 353 & 374 & 1770 & 20.33 \\
\hline 53 & 100 & 0 & & & & 0 & 730 & 1768 & 20.96 \\
\hline & 90 & 10 & & & & 71 & 657 & 1766 & 22.86 \\
\hline & 80 & 20 & 0.55 & 187 & 851 & 141 & 584 & 1763 & 23.01 \\
\hline & 70 & 30 & 0.55 & 181 & 851 & 212 & 511 & 1761 & 24.80 \\
\hline & 60 & 40 & & & & 283 & 438 & 1759 & 19.54 \\
\hline & 50 & 50 & & & & 353 & 365 & 1756 & 18.88 \\
\hline
\end{tabular}

Table 4. Mix proportions of concrete specimens made with ladle furnace slag aggregate.

\begin{tabular}{|c|c|c|c|c|c|c|c|c|c|c|}
\hline \multirow{3}{*}{\multicolumn{2}{|c|}{$\begin{array}{c}\text { Replacement } \\
(\%)\end{array}$}} & \multirow{4}{*}{ W/C } & \multirow{4}{*}{$\mathbf{f} / \mathbf{a}$} & \multirow{2}{*}{\multicolumn{5}{|c|}{ Mix proportions, $\mathrm{kg} / \mathrm{m}^{3}$}} & \multirow{4}{*}{$\begin{array}{c}\text { Unit } \\
\text { Weight } \\
\text { of fresh } \\
\text { concrete } \\
\left(\mathrm{kg} / \mathrm{m}^{3}\right)\end{array}$} & \multirow{4}{*}{$\begin{array}{l}\text { 28-day } \\
\text { comp. } \\
\text { strength } \\
\text { (MPa) }\end{array}$} \\
\hline & & & & & & & & & & \\
\hline & & & & \multirow[b]{2}{*}{ Cement } & \multirow[b]{2}{*}{ Water } & \multicolumn{2}{|c|}{$\begin{array}{c}\text { Fine } \\
\text { aggregate }\end{array}$} & \multirow[t]{2}{*}{$\begin{array}{c}\text { Coarse } \\
\text { aggregate }\end{array}$} & & \\
\hline $\begin{array}{l}\text { Natural } \\
\text { River } \\
\text { sand }\end{array}$ & LFS & & & & & $\begin{array}{c}\text { River } \\
\text { sand }\end{array}$ & LFS & & & \\
\hline \multirow{2}{*}{100} & \multirow{2}{*}{0} & \multirow{3}{*}{0.45} & 0.44 & \multirow{3}{*}{340} & \multirow{3}{*}{153} & 796 & 0 & 855 & 2144 & 19.8 \\
\hline & & & 0.48 & & & 869 & 0 & 794 & 2156 & 21.6 \\
\hline 90 & 10 & & 0.44 & & & 717 & 82 & 855 & 2147 & 21.2 \\
\hline
\end{tabular}




\begin{tabular}{|c|c|c|c|c|c|c|c|}
\hline & & 0.48 & 782 & 89 & 794 & 2158 & 22.8 \\
\hline \multirow{2}{*}{80} & \multirow{2}{*}{20} & 0.44 & 637 & 163 & 855 & 2148 & 22.4 \\
\hline & & 0.48 & 695 & 178 & 794 & 2160 & 23.6 \\
\hline \multirow{2}{*}{70} & \multirow{2}{*}{30} & 0.44 & 557 & 245 & 855 & 2150 & 22.1 \\
\hline & & 0.48 & 608 & 267 & 794 & 2162 & 23 \\
\hline
\end{tabular}

\section{Compressive Strength}

The 28-day compressive strength of cylindrical concrete specimens made with $0 \% \sim 50 \%$ replacement ratios of BFA from different sources (S1, S2, S3) is shown in Fig. 5. It can be observed from the figure that the compressive strength of concrete is found maximum at a replacement ratio of 30\% irrespective of different W/C ratios and sources of the brick fine aggregate investigated. The brick fine aggregate also improves the compressive strength of concrete by internal curing up to 30\% BFA replacement ratio. Beyond 30\% BFA replacement ratio, the compressive strength of concrete started to reduce. It is due to the inadequate amount of cement paste required for lubricating the aggregates in concrete. Fig. 5 also shows that although for W/C of 0.50 the compressive strength of concrete specimens made with 0\% 50\% BFA replacement ratios did not show much variation in terms of the sources of brick fine aggregate, a significant amount of variation was observed in the compressive strength of concrete for W/C of 0.55 . Fig. 6 shows the 28-day compressive strength of concrete specimens made with $0 \%, 10 \%, 20 \%$ and $30 \%$ replacements of river sand by LFS fine aggregate. It is observed that compressive strength increased with the increase of percentage replacement of natural river sand by LFS up to $20 \%$ and then decreased slightly at $30 \%$ replacement ratio.

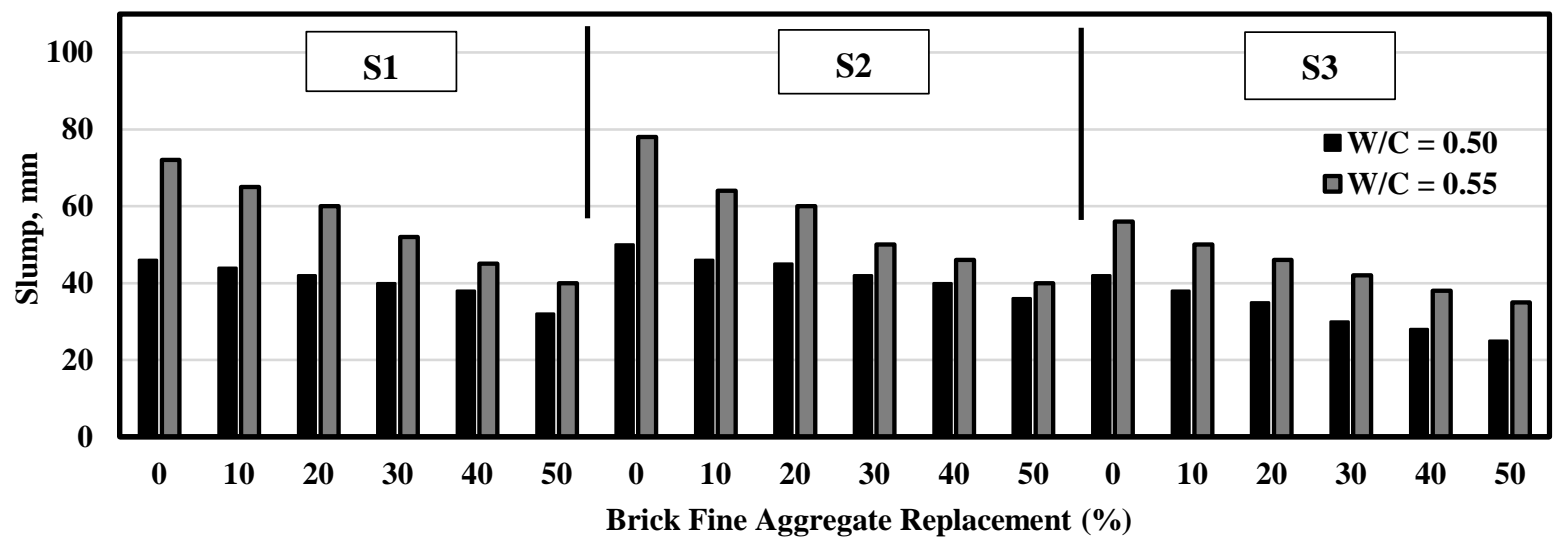

Fig. 3. Workability of concrete made with different replacement ratios of BFA. 


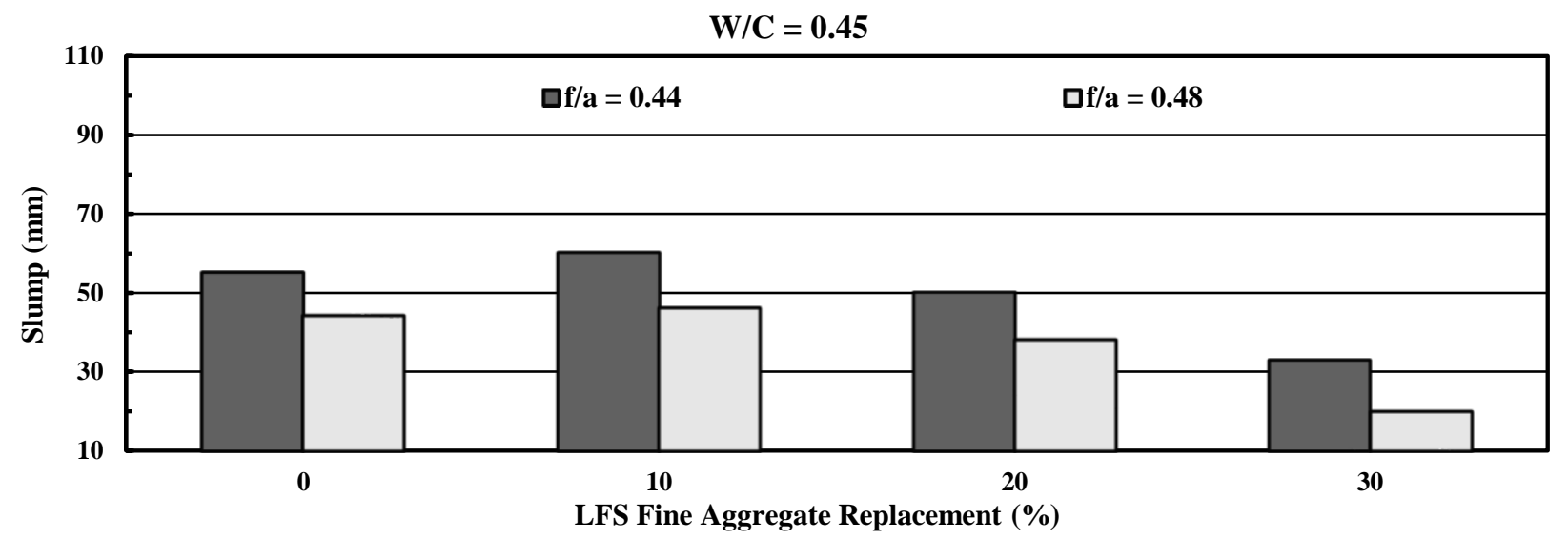

Fig. 4. Workability of concrete made with different replacement ratios of LFS.

When river sand was replaced by LFS at a percentage $20 \%$, the high angularity of LFS aggregate led to increase the bond between LFS particles and cement paste which increased the compressive strength of concrete initially. As LFS is finer than natural sand, it also helps to fill some smaller voids and thereby increase the compressive strength of concrete. The possible reason of strength reduction beyond $20 \%$ replacement may be related to the increased amount of fine particles in concrete and the reduced workability. Since LFS contains more fines than river sand, LFS particles would require more cement to be effectively coated. Therefore, compressive strength of concrete would reduce for high percentage replacement of river sand by LFS. Again, high percentage replacement of river sand by LFS would cause substantial reduction in workability (Fig. 4), which would lead to formation of less dense concrete and eventually cause reduction in strength.

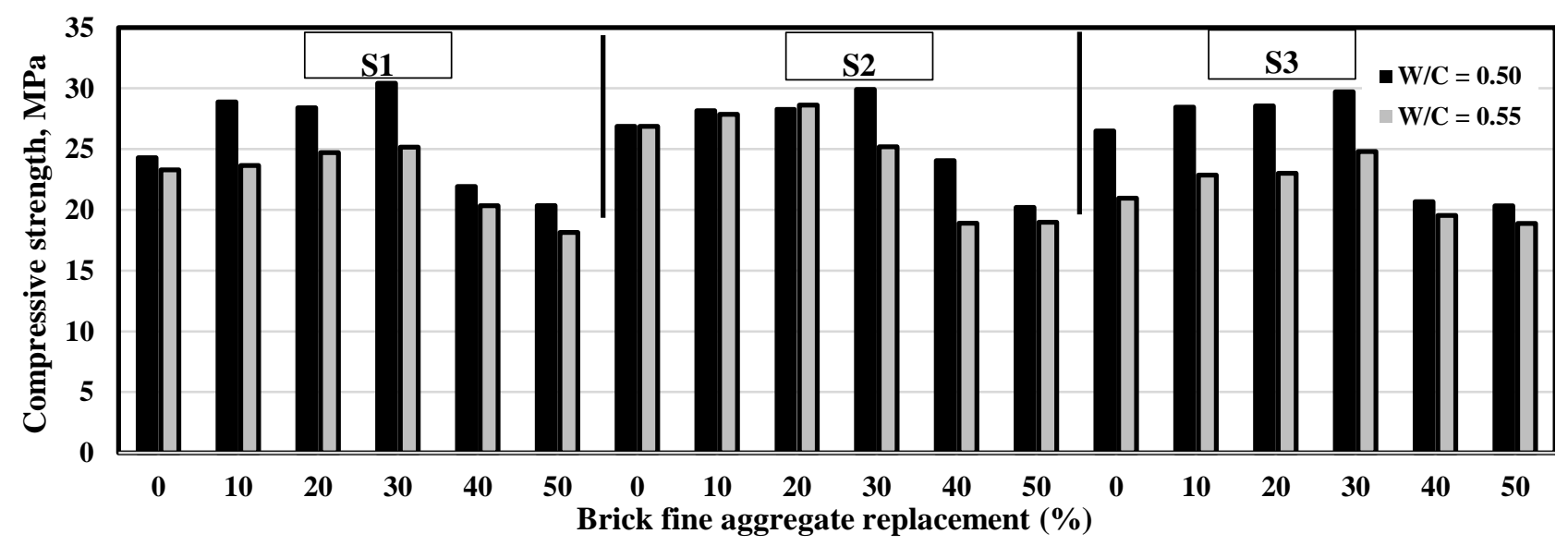

Fig. 5. Compressive strength of concrete made with $0 \%-50 \%$ replacement ratios of BFA. 


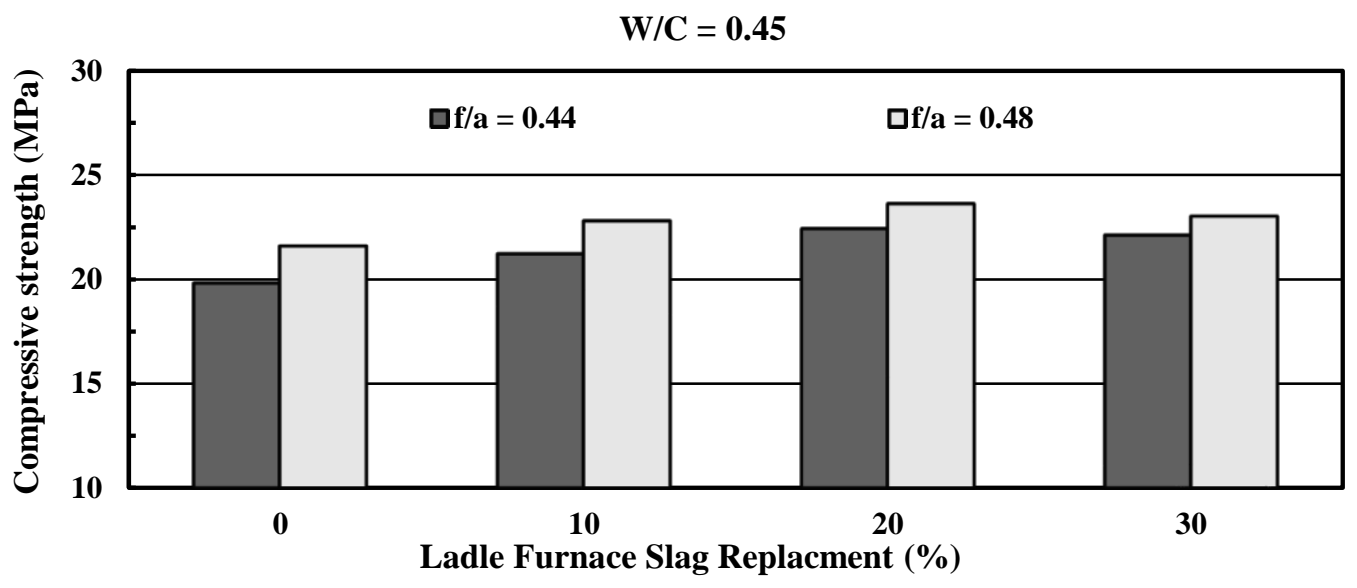

Fig. 6. Compressive strength of concrete made with $0 \%-30 \%$ replacement ratios of LFS.

\section{Tensile Strength and Modulus of Elasticity of Concrete}

Fig. 7 shows the tensile strength and modulus of elasticity of concrete specimens made with brick fine aggregate for different replacement ratios. Results presented in Fig. 7 confirm that the trend of tensile strength and modulus of elasticity of the concrete specimens are similar to that of the compressive strength of concrete made with BFA. Both optimum tensile strength and modulus of elasticity are found to be at $30 \%$ replacement ratio.

The 28-day splitting tensile strength and modulus of elasticity of concretes made with $0 \%, 10 \%$, $20 \%$ and $30 \%$ replacements of river sand by LFS aggregate are shown in Fig. 8. Similar to the compressive strength test results shown in Fig. 6, the optimum tensile strength and modulus of elasticity was found at $20 \%$ replacement when brick aggregate was used as coarse aggregate.

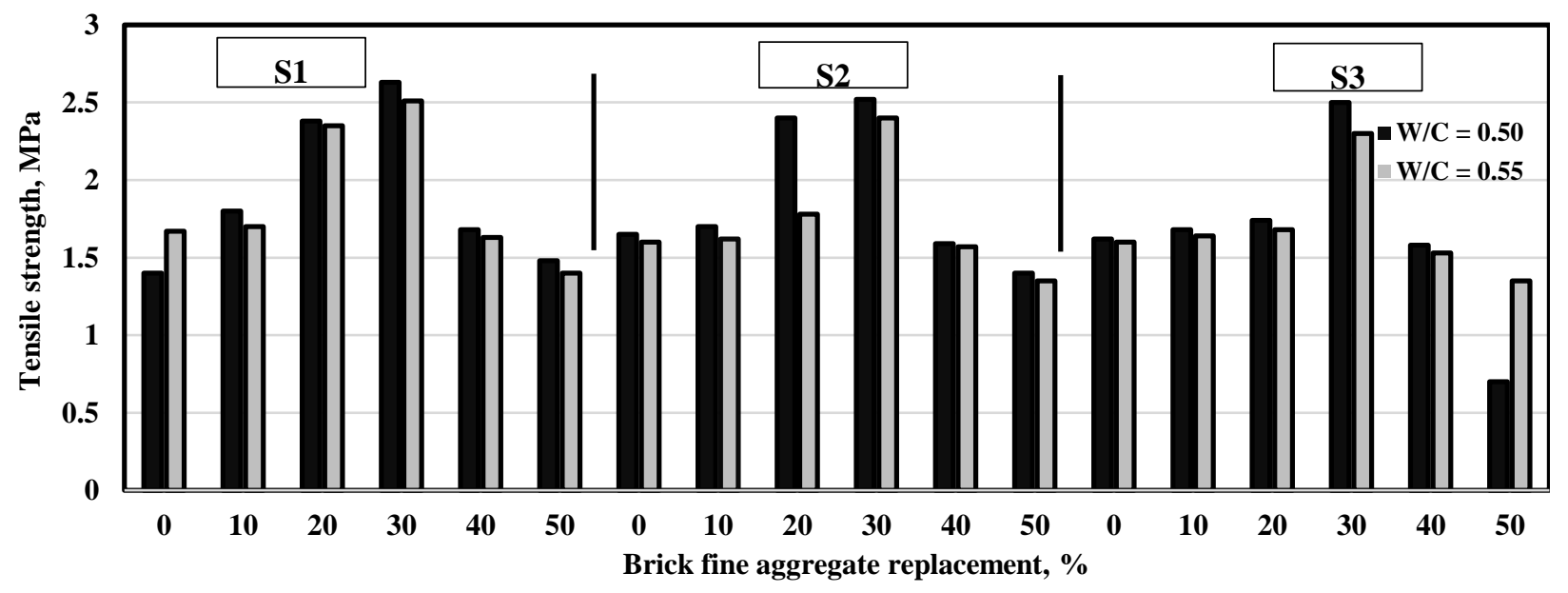




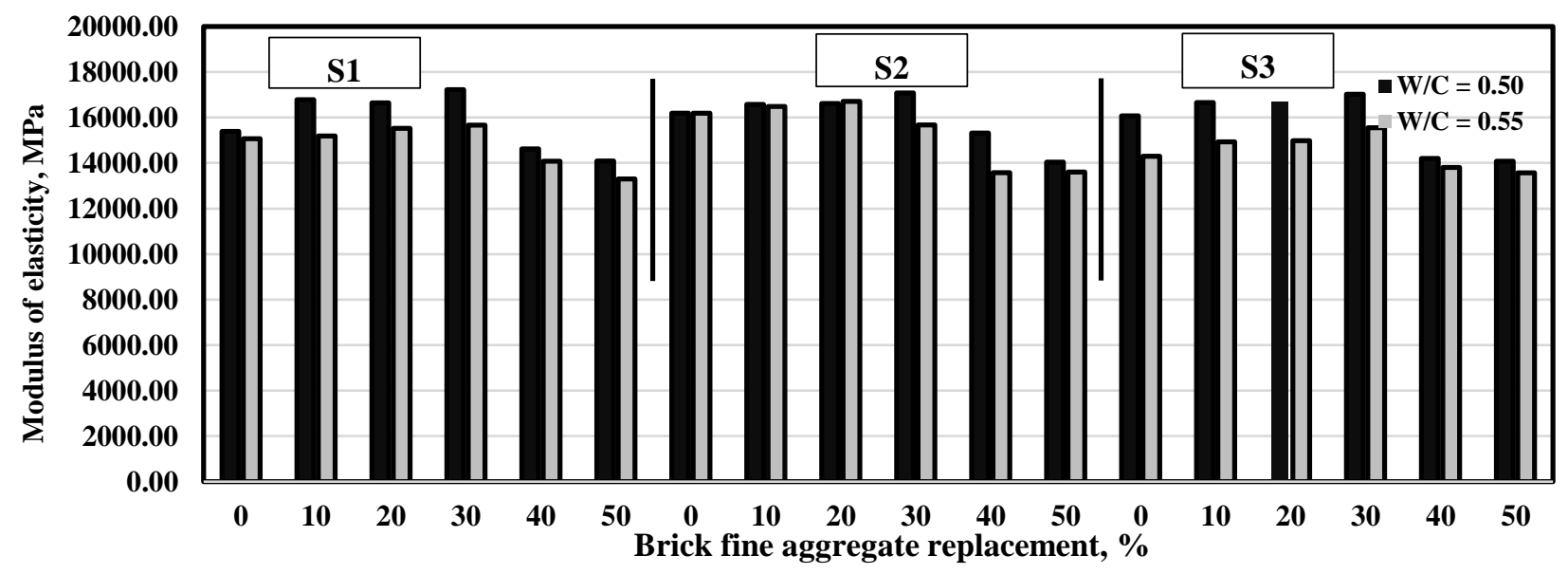

Fig. 7. 28-day tensile strength and modulus of elasticity of concretes made with BFA.
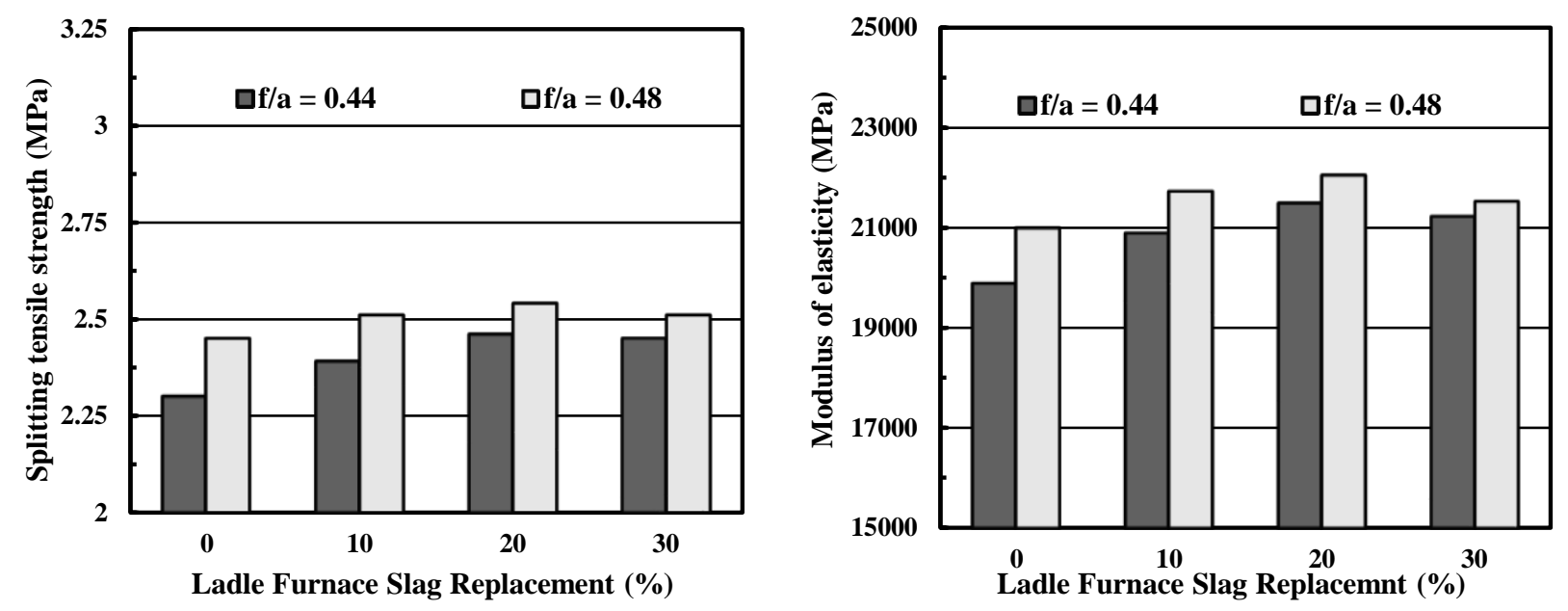

Fig. 8. 28-day tensile strength and modulus of elasticity of concretes made with LFS.

\section{CONCLUSIONS}

Based on the results of this experimental investigation on utilization of BFA and LFS as fine aggregates in concrete, the following conclusions are drawn:

1. Workability of concrete decreases with increasing replacement of natural river sand by BFA irrespective of the source,

2. Workability of concrete increases with increasing replacement of river sand by LFS up to $20 \%$, and then the workability starts to reduce with further replacement of river sand by LFS. 
3. Compressive strength, splitting tensile strength and modulus of elasticity of concrete increase with increasing replacement of river sand by BFA up to $30 \%$, beyond that, the hardened properties of concrete start to reduce.

4. compressive strength, splitting tensile strength and modulus of elasticity of concrete increase with increasing replacement of river sand by LFS up to $20 \%$, and then start to reduce.

\section{REFERENCES}

Adolfsson, D., Robinson, R., Engström, F., Björkman, B., 2011. Influence of mineralogy on the hydraulic properties of ladle slag. Cem. Concr. Res. 41, 865-871. doi:10.1016/j.cemconres.2011.04.003

Akhtaruzzaman, A.A., Hasnat, A., 1986. Shear and Flexural Behavior of Brick-Aggregate Concrete Beams without Web Reinforcement. ACI Mater. J. 83, 284-289. doi: $10.14359 / 10418$

Akhtaruzzaman, A.A., Hasnat, A., 1983. Properties of Concrete Using Crushed Brick as Aggregate. Concr. Int. 5, 58-63.

Bektas, F., Wang, K., Ceylan, H., 2009. Effects of crushed clay brick aggregate on mortar durability. Constr. Build. Mater. 23, 1909-1914. doi:10.1016/j.conbuildmat.2008.09.006

Cachim, P.B., 2009. Mechanical properties of brick aggregate concrete. Constr. Build. Mater. 23, 1292-1297. doi:10.1016/j.conbuildmat.2008.07.023

Debieb, F., Kenai, S., 2008. The use of coarse and fine crushed bricks as aggregate in concrete. Constr. Build. Mater. 22, 886-893. doi:10.1016/j.conbuildmat.2006.12.013

John, A., John, E., 2013. Study on the partial replacement of fine aggregate using induction furnace slag. Am. J. Eng. Res. 4, 1-5.

Kockal, N.U., 2016. Investigation about the effect of different fine aggregates on physical, mechanical and thermal properties of mortars. Constr. Build. Mater. 124, 816-825.

Kothai, P. S., and R.M., 2014. Utilization of steel slag in concrete as a partial replacement material for fine aggregates. Int. J. Innov. Res. Sci. Eng. Technol. 3, 11585-11592.

Mohammed, T.U., Hasnat, A., Awal, M.A., Bosunia, S.Z., 2015. Recycling of Brick Aggregate Concrete as Coarse Aggregate. J. Mater. Civ. Eng. 27, B4014005(1)-B4014005(9).

Mohammed, T.U., Hassan, M., 2015. Utilization of Brick Fine Aggregate in Concrete, in: International Conference on Regeneration and Conservation of Concrete Structures (RCCS). Nagasaki, Japan, p. CD Proceedings, Paper No. I-21, pp. 1-11.

Mohammed, T.U., Mahmood, A.H., 2016. Effects of maximum aggregate size on UPV of brick $\begin{array}{llll}\text { aggregate } & \text { concrete. } & \text { Ultrasonics } & 69,\end{array}$ doi:http://dx.doi.org/10.1016/j.ultras.2016.04.006 
Mohammed, T.U., Rahman, M.N., Mahmood, A.H., Hasan, T., Apurbo, S.M., 2016. Utilization of Steel Slag in Concrete as Coarse Aggregate, in: 4th International Conference on Sustainability of Construction Materials and Technologies (SCMT4). Las Vegas, USA, p. Paper No.-S184.

Pellegrino, C., Cavagnis, P., Faleschini, F., Brunelli, K., 2013. Properties of concretes with black/oxidizing electric arc furnace slag aggregate. Cem. Concr. Compos. 37, 232-240. 